\title{
Natural Schistosoma mansoni Infection in Nectomys squamipes: Histopathological and Morphometric Analysis in Comparison to Experimentally Infected $\mathrm{N}$. squamipes and $\mathrm{C} 3 \mathrm{H} / \mathrm{He}$ mice
}

\author{
Michele Costa-Silva/ ${ }^{++}$, Rosângela Rodrigues-Silva*, Maarten Hulstijn, \\ Renata Heisler Neves, Mônica de Souza Panasco**/++++, Henrique Leonel Lenzi**/+++, \\ José Roberto Machado-Silva/ ${ }^{+} /+++$
}

Departamento de Patologia e Laboratórios, Faculdade de Ciências Médicas, Universidade do Estado do Rio de Janeiro, Rua Prof. Manuel de Abreu 444, $5^{\circ}$ andar, 20550-170 Rio de Janeiro, RJ, Brasil *Laboratório de Helmintos Parasitos de Vertebrados, Departamento de Helmintologia **Departamento de Patologia, Instituto Oswaldo Cruz-Fiocruz, Rio de Janeiro, RJ, Brasil

Histopathologic and morphometric (area, perimeter, major and minor diameters) analysis of hepatic granulomas isolated from twelve naturally infected Nectomys squamipes were compared to four experimentally infected ones and six C3H/He mice. Liver paraffin sections were stained for cells and extracellular matrix. Both groups of $\mathrm{N}$. squamipes presented peculiar granulomas consisting predominantly of large macrophages, full of schistosome pigment, characterizing an exudative-macrophage granuloma type, smaller than the equivalent granuloma type in mouse. Naturally infected animals exhibited granulomas in different stages of development, including large number of involutional types. Morphometric analysis showed that all measurements were smaller in naturally infected animals than in other groups. The results demonstrated that both $\mathrm{N}$. squamipes groups reproduced, with small variations, the hepatic granuloma aspects already described in cricetidium (Calomys callosus), showing a genetic tendency to set up strong macrophage responses and small granulomas. Unexpectedly, natural infection did not engender distinguished histopathological characteristics distinct from those derived from experimental single infection, showing changes predominantly secondary to the duration of infection. It appears that the variability of the inocula (and the number of infections?) interfere more with the quantity than with the quality of the pathological changes, denoting some morpho-functional determinism in the response to schistosomal infection dependent on the animal species.

Keys words: Schistosoma mansoni - Nectomys squamipes - C3H/He mice - hepatic granuloma - histopathology - morphometry

Several authors have shown that rodents in Africa or in Neotropical areas can harbor Schistosoma mansoni infection (Théron et al. 1992, Alarcón de Noya et al. 1997, Morand et al. 1999, Duplantier \& Sène 2000). In Brazil, several reports indicated that Nectomys squamipes Brants 1827 (Rodentia: Sigmondontinae) has an important role in the transmission of this helminthiasis depending on special ecological conditions (Rey 1993, D'Andrea et al. 2000). $N$. squamipes, semiaquatic species of Sigmodontinae, is distributed along watercourse banks and has a wide geographic range coincident with $S$. mansoni endemic areas (Ribeiro et al. 1998).

This work is part of a MSc Thesis in Morphology, Instituto de Biologia, Uerj, RJ, Brasil.

${ }^{+}$Corresponding author. Fax: +55-21-2587.6112. E-mail: machado@uerj.br

${ }^{++}$Fellowship, Fundação Carlos Chagas Filho de Amparo à Pesquisa do Estado do Rio de Janeiro.

${ }^{+++}$Fellowship, Conselho Nacional de Desenvolvimento Científico e Tecnológico

${ }^{++++}$Fellowship, Coordenação de Aperfeiçoamento de Pessoal de Nível Superior.

Received 18 June 2002

Accepted 15 August 2002
Laboratory studies have demonstrated that $N$. squamipes is highly susceptible to experimental $S$. mansoni infection (Rodrigues-Silva 1988, Souza et al. 1992, Maldonado Jr. et al. 1994, Ribeiro et al. 1998). It presents a well-balanced relationship with the parasite, since life-long infections do not affect its life span (RodriguesSilva et al. 1992) or its reproductive capacity (D'Andrea et al. 2000), therefore being considered a permissive host (Machado-Silva et al. 1997).

Mature eggs of $S$. mansoni retained in the intestine and liver tissues of immunological competent hosts induce granuloma formation, which regulation and morphological aspects vary among different mice strains and animal species (Cheever et al. 1998). For instance, hepatic granulomas of Calomys callosus (Rodentia: Cricetidae) are $27 \%$ smaller than granulomas from albino mice at the same time of infection (Lenzi et al. 1995). The granuloma variability is due to the fact that this organized structure is composed by host and parasite components, functioning as a hybrid interface between two different phylogenetic beings, depending, therefore, on the host epigenetic characteristics (Lenzi et al. 1998a).

Most studies of the granulomatous reaction seen in literature, except in human cases, make use of experimentally infected animals, introducing into the analysis inexorable artificial variables. Here we present an interesting animal model (N. squamipes) which takes part in the maintenance of $S$. mansoni life-cycle in one endemic area, 
pointing out the qualitative and quantitative histopathological aspects of hepatic granulomas following natural infection. The data were compared with granulomas from $N$. squamipes and $\mathrm{C} 3 \mathrm{H} / \mathrm{He}$ mice born and infected under laboratory conditions.

\section{MATERIALS AND METHODS}

Animals and $S$. mansoni infection - Twelve specimens of naturally infected $N$. squamipes $(2 \mathrm{n}=56$ chromossomes) (Bonvicino et al. 1996) were captured in the Pamparrão Valley, District of Sumidouro, State of Rio de Janeiro, Brazil, and eleven were killed in accordance with animal ethical practice seven days after their capture (RodriguesSilva et al. 1992). One animal, after the capture, was maintained in the laboratory for 490 days before its necropsy.

From the feces of these animals, a $S$. mansoni isolate was obtained ( $\mathrm{R}$ isolate), and the methodology applied for its isolation and maintenance in laboratory was already presented in another publication (Machado-Silva et al. 1994). Briefly, specimens from a sympatric Biomphalaria glabrata colony, kept under laboratory conditions, were exposed to ten miracidia. The snails were maintained in glass aquariums and fed ad libitum with fresh lettuce (Lacttuca sativa). The cercariae eliminated after exposure of snails to a light source were used for experimental infection.

Four specimens of $N$. squamipes and six $\mathrm{C} 3 \mathrm{H} / \mathrm{He}$ mice were infected by percutaneous exposure to 500 and 50 cercariae respectively, and were killed in the same manner as naturally infected ones at 52 and 62 days after infection, respectively.

Histopathological analysis - Liver fragments taken from the right lobule of each animal, was fixed in Carson's modified Millonig's phosphate-buffered formalin, $\mathrm{pH} 7.4$ (Carson's formalin-Millonig) (Carson et al. 1973) and embedded in paraffin. Sections $(5 \mu \mathrm{m})$ were stained with hematoxilin and eosin (H\&E); PAS-Alcian Blue, $\mathrm{pH}=1.0$ and 2.5; Lennert's Giemsa (Lennert 1978); Gomori's reticulin stains, Sirius red pH = 10.2 (eosinophils) (Bogomoletz 1980, Luque \& Montes 1989, Vale et al. 1997); Masson's trichrome, Alcian blue/safranin (mast cell subpopulation) (Strobel et al. 1981) and Picrosirius \pm polarization microscopy (Junqueira et al. 1979) and Weigert resorcin-fuchsin \pm oxidation with potassium peroxymonosulfate (Oxone ${ }^{\circledR}$ monopersulfate compound, Sigma 22,803-6). Digital images were captured with Hamamatsu color chilled 3 CCD camera (model C-5810), stored with tagged-image file format (TIF) and printed in Codonics NP-1600 Photographic dye-sublimation Printer.

Morphometric analysis - Brightfield microscopy (Olympus BX50) was used to evaluate the sections. Images were captured by an analogue camera (Sony, $640 \mathrm{x}$ 480 pixels, RGB) and transferred to a computer containing software for image analysis (Image Pro Plus - Media Cybernetics). Morphometric analysis of the granulomas was performed measuring the following parameters: area, perimeter, major and minor diameter. Only granulomas with eggs visible in the centre were analyzed.

Statistical analysis - One-way ANOVA was applied using the post hoc Tuckey test to compare data from each group individually. Measurements with $p$ values $\leq 0.05$, were considered significantly different (Vieira 1991).

\section{RESULTS}

Histopathological results

Naturally infected N. squamipes - Livers from naturally infected $N$. squamipes showed peri-ovular lesions in pre-granulomatous stages, characterized by exudative (Fig. 1), exudative-necrotic reactions (Fig. 2), and clear granulomatous stages in different developmental phases such as exudative-productive (Fig. 3), productive (Fig. 4) and involutional subtypes (Figs 17-22). The exudative-productive and involutional granulomas predominated in number and the former were composed of a large macrophagic central layer, surrounded by an external one consisting of lymphocytes, plasma cells and pigmented macrophages with variable number of eosinophils (Fig. 3). These two layers were sharply demarcated by a reticular scaffold, forming a mesh with concentricity of the fibers (Figs 5, 6). Sometimes, in large portal exudative-productive granulomas three layers were clearly defined by the arrangement of reticular fibers: inner, internal or paucifibrillar zone, which consisted of macrophages; the middle or paracentral zone rich in fibers and the external zone, predominantly cellular with scarce amount of fibers (Fig. 6). These portal granulomas expressed large amounts of interstitial collagens marked by Picrosirius in brightfield (Figs 7, 9, 11,13 ) or in polarization microscopies (Figs 8, 10, 12, 14). The intragranulomatous collagenic disposition presented two patterns: one central or centrifugal (Figs 7-10) and an another concentric and peripheral, that tended to make a delimiting fibrotic pseudocapsule (Figs 7-10) which became exacerbated in productive granulomas, showing a centripetal tendency or a peripheral to central decrescent gradient (Figs 11-14). The advanced or fibrotic productive granulomas were spherical composed mainly by fibroblast-like cells (fibroblasts or myofibroblasts?), displaying sometimes hyalinization of collagen stroma (Figs $15,16)$. Involutional stages of granulomas were frequent, varying from transitional forms between advanced-productive to early involutional (Fig. 17), involutional with thick (Fig. 18) or thin (Figs 19, 20) collagen layer or predominantly pigmented macrophagic type (Figs 21, 22). Small lymphocytes were often detected in these types of involutional granulomas, located together with the pigmented macrophages or making a peripheral halo (Figs $17-20,22)$. The variegated granuloma types cohabited simultaneously in the liver of each individual animal (Figs $23,24)$. Some granulomas developed intravascularly in portal veins, displacing the vascular wall to the periphery (Figs 25, 29, 30).

The expression of high or low ph proteoglycans in the granulomas was not homogeneous, being more intense in the granulomas of animals with morphological evidence of more chronic infection.

Numerous mast cells, sometimes in degranulation were detected in granulomas or mainly in the connective tissue of portal spaces close or not to granulomas (Figs 26-29). They were alcian blue positive in Strobel stain (Fig. 27), being also more alcian blue positive in $\mathrm{pH} 1.0$ than in $\mathrm{pH}$ 2.5 . They stained highly dark with resorcin-fuchsin without oxidation (Fig. 29), becoming weak or negative after oxidation with oxone (Fig. 30). 
Portal spaces, beyond mast cells, exhibited plasma cells and less frequently eosinophils, macrophages with or without schistosome pigment and lymphoid aggregates. Portal and periportal fibrosis, and bridging fibrous septa connecting portal spaces or portal spaces to central zones were changeful and usually the fibrosis was related to the presence of granulomas. Some portal spaces showed dilated lymphatic vessels.
The Kupffer's cells were hypertrophic, containing variable amount of schistosome pigment, and small and isolated parenchymatous necrosis was seen close to granulomas. All granulomas types were seen in naturally infected animals although productive-fibrotic was predominant.

Experimentally infected N. squamipes - The four experimentally infected animals with 52 days of infection
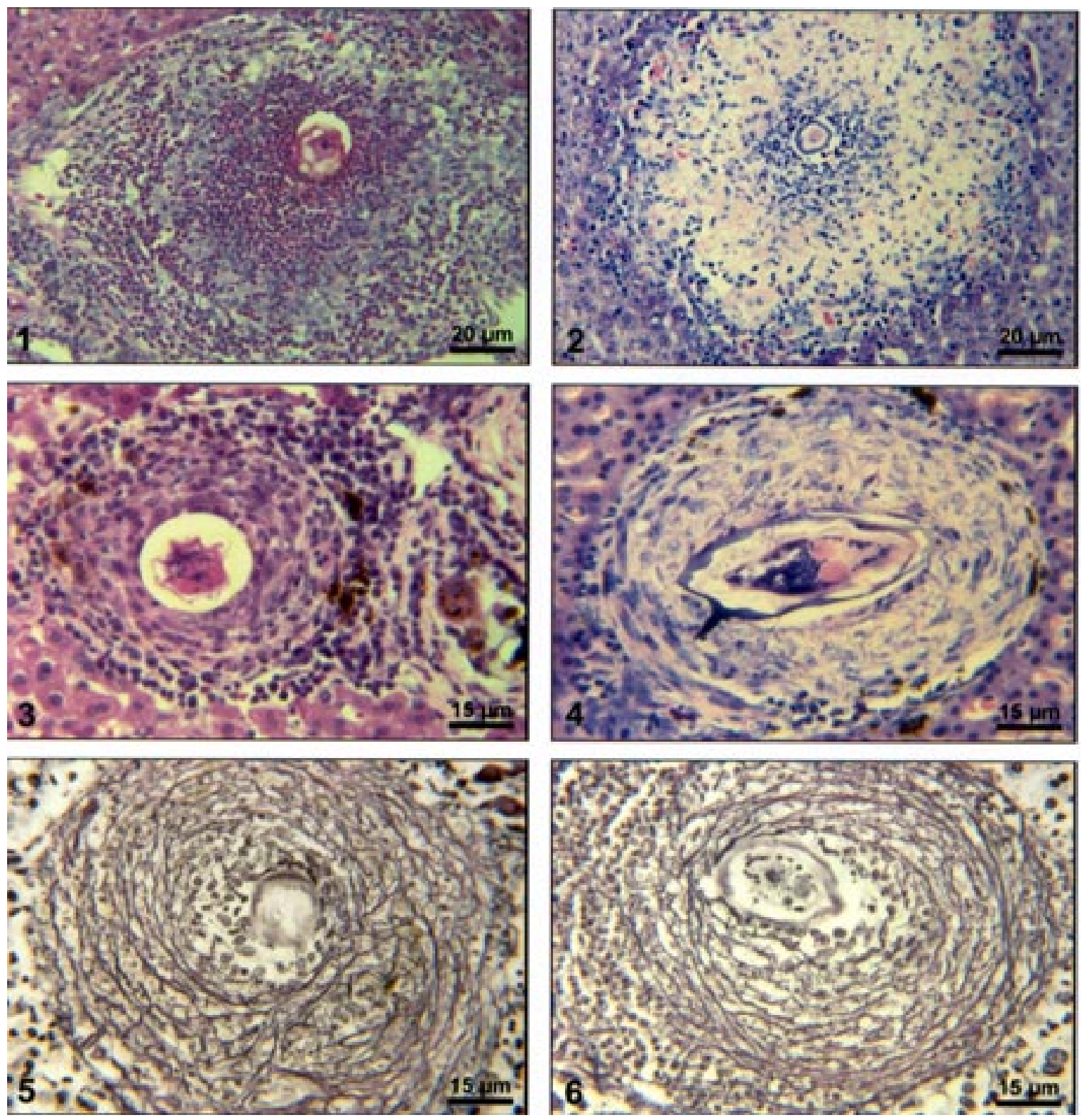

Hepatic schistosomal granulomas in naturally infected Nectomys squamipes - Exudative granuloma rich in eosinophils diffusely distributed with focal concentration around the egg (Fig. 1). Exudative-necrotic granuloma (Fig. 2). Exudative-productive granuloma with predominance of large macrophages (exudative-productive macrophagic-type), forming an exuberant central zone surrounded by a halo of mononuclear cells (lymphocytes, monocytes and pigmented macrophages). Close to the granuloma there is one pigmented giant cell (Fig. 3). Exuberant exudative-productive macrophagic-type consisting essentially of macrophages, encircling an egg with viable miracidium (Fig. 4). Exudative-productive granuloma in transitional stage to early productive, showing concentric arrangement of reticular fibers (Figs 5, 6). [H\&E (Figs 1, 3); Lennert's Giemsa (Figs 2, 4); Gomori’s reticulin (Figs 5, 6)]. 
showed a limited pattern of granulomas. The animals displayed a weak or initial peri-ovular reaction, exudative (Fig. 31) and exudative-necrotic pre-granulomatous stages, exudative-productive (Figs 32, 34), pure macrophagic (Fig. 33), small fibrotic-macrophagic (Figs 37, 38), and more scarcely productive (Fig. 39) and involutional (Fig. 40) granulomas. The macrophagic variations of granulomas were the predominant types. The granulomas expressed simultaneously high and low sulphated proteoglycans, and presented less amount of collagen than in the naturally infected animals (Figs 35, 36).

The patterns of portal and septal fibrosis and the Kupffer's cells changes were similar to those described in the naturally infected group. However, two animals showed some portal lymphatic vessels with lumen prominently expanded and full of macrophages (Fig. 41), and, in
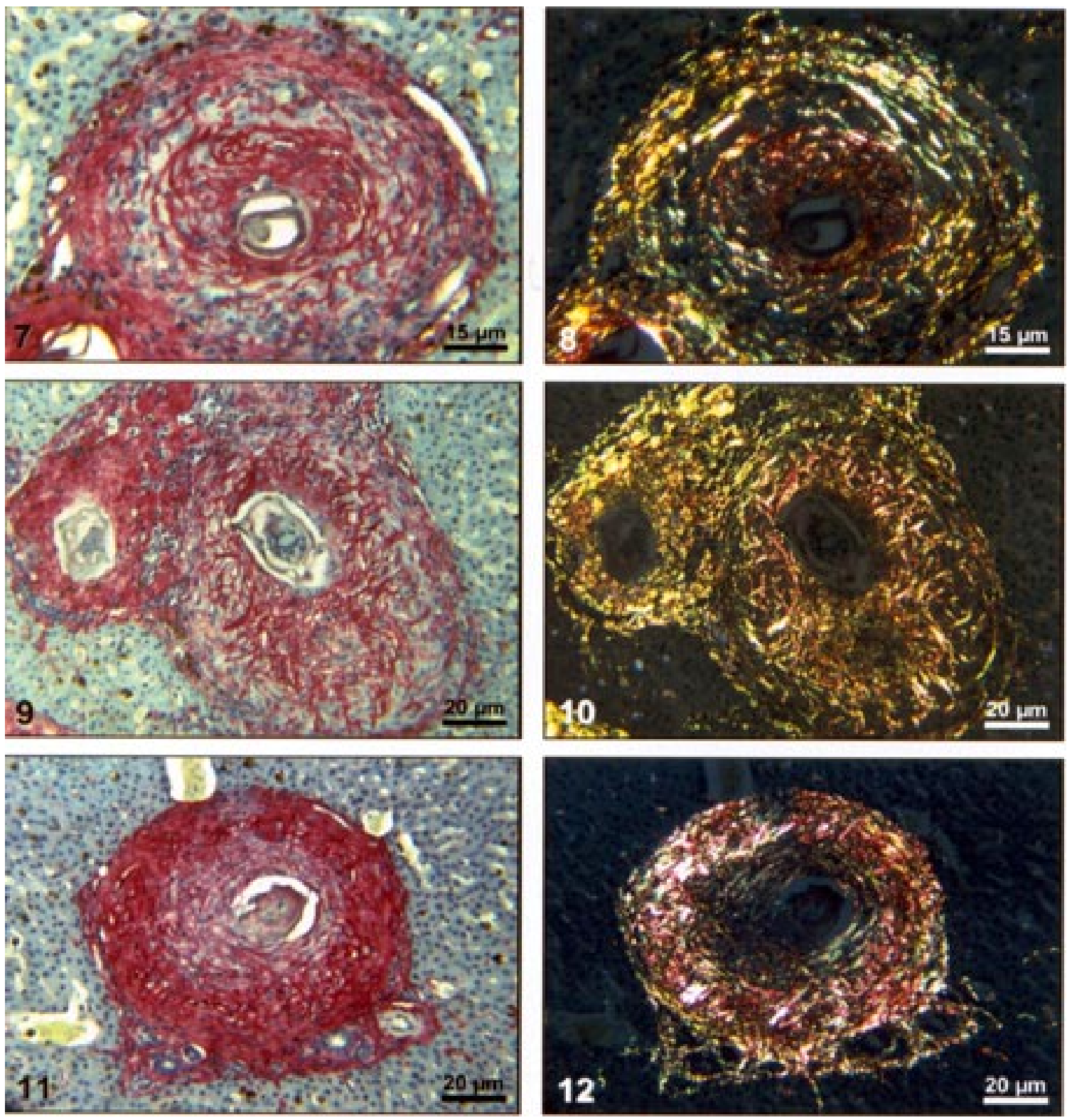

Hepatic schistosomal productive granulomas in naturally infected Nectomys squamipes - Two fibrogenic zones inside granulomas with concentric arrangement, one originating close to the eggs (centrifugal $=$ in-out) and another delineating the limiting cellular plate with the parenchyma $($ centripetal $=$ out-in) $($ Figs 7,8$)$; Radial distribution of collagen fibers in central $($ centrifugal $=$ in-out $)$ fibrogenic zone $($ Figs 9,10). Advanced productive granuloma with a decrescent out-in fibrosis, presenting a dense and concentric distribution of collagen fibers (Figs 11, 12) [Picrosirius without (Figs 7, 9, 11) and with polarization microscopy (Figs 8, 10, 12)]. 
general, the animal of this group presented more focal parenchymatous necrosis (Fig. 42).

Experimentally infected $\mathrm{C} 3 \mathrm{H} / \mathrm{He}$ mice - Mice with 62 days of infection presented exudative peri-ovular lesions and a clear predominance of exudative-productive granulomas, without evidence of more advanced stages of the granulomatous reaction (Fig. 43). Like the $N$. squamipes, focal areas of parenchymatous necrosis arose close to some granulomas (Fig. 44). The pattern of architectural arrangement of collagen fibers inside the granulomas tended to define a trellis-like or storiform disposition, making radial extensions to adjacent parenchyma (Figs 45-47) and presenting several fiber anchorage points or fiber radiation centers (Fig. 48).

Schematic comparative views between granuloma types and patterns of extragranulomatous fibrosis ob-
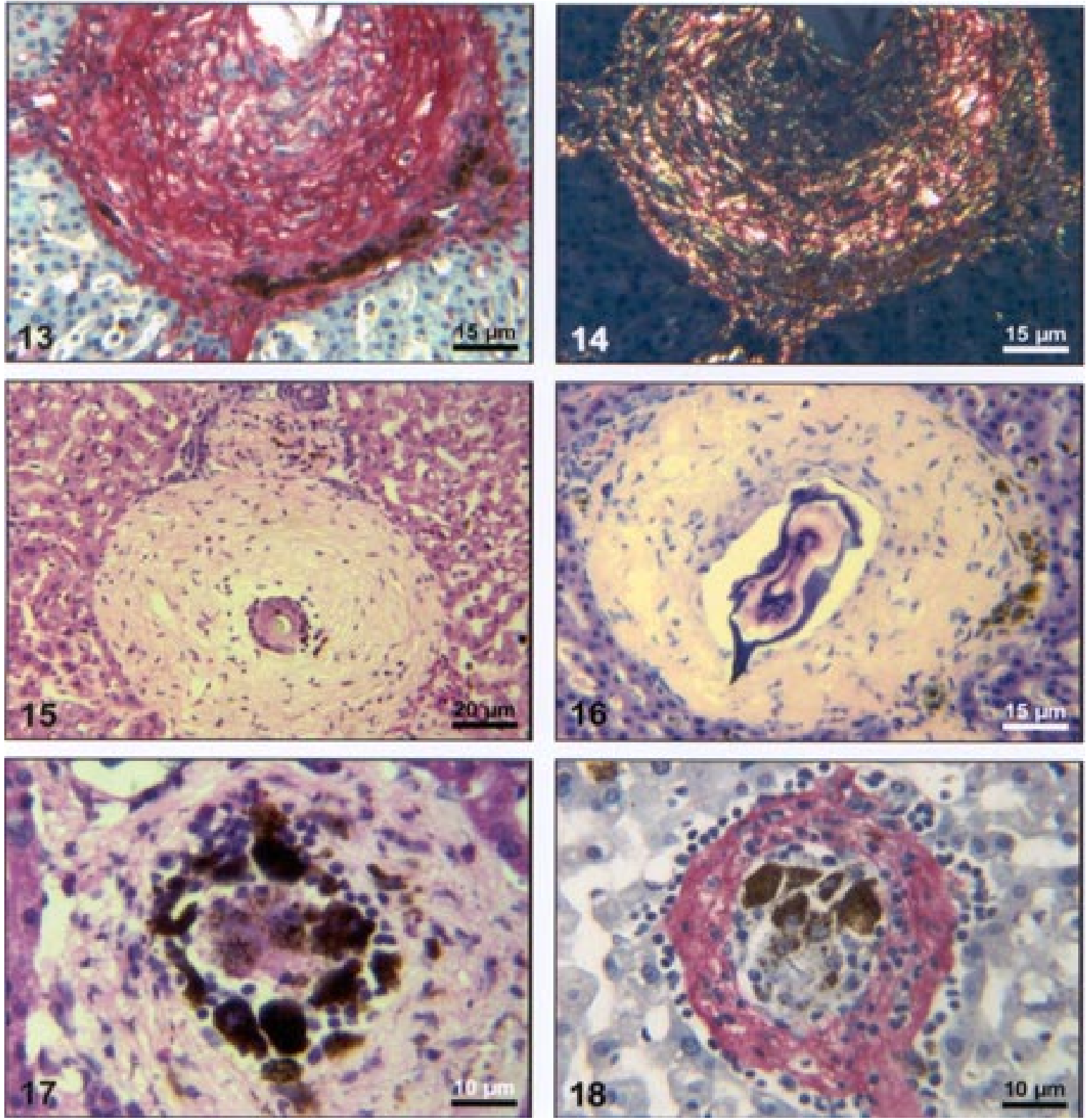

Hepatic schistosomal granulomas in naturally infected Nectomys squamipes- Advanced or fibrotic productive granulomas with dense and concentric fibrosis (Figs 13-15), presenting also hyalinization of the collagen fibers (Fig. 16). Advanced productive granuloma in transition to involutional stage centered by dead miracidium surrounded by pigmented macrophages intermixed with lymphocytes (Fig. 17). Involutional granuloma with thick collagen layer presenting large number of lymphocytes inside and forming a circle round its periphery (Fig. 18) [Picrosirius without (Figs 13, 18) and with polarization (Fig. 14); H \& E (Figs 15, 17); Lennert's Giemsa (Fig. 16)]. 
served in natural and experimentally infected $N$. squamipes groups are displayed in Figs 49 and 50.

Morphometric results - Morphometric analysis showed that all measurements of liver granulomas evaluated in sections stained with $\mathrm{HE}$ or Gomori's reticulin were smaller in naturally infected animals than in the other two groups. Mice displayed the largest values while measurements of experimentally infected $N$. squamipes were intermediate (Table I, II). Comparing all parameters among the three groups, there were highly significant differences between $N$. squamipes and the mice $(\mathrm{p}<0.001)$.

\section{DISCUSSION}

This paper focused on the morphological aspects of hepatic changes in naturally $S$. mansoni infected $N$. squamipes, showing evidence of active infection expressed by frequent viable miracidia inside the eggs and recent pre-granulomatous and granulomatous peri-ovu-
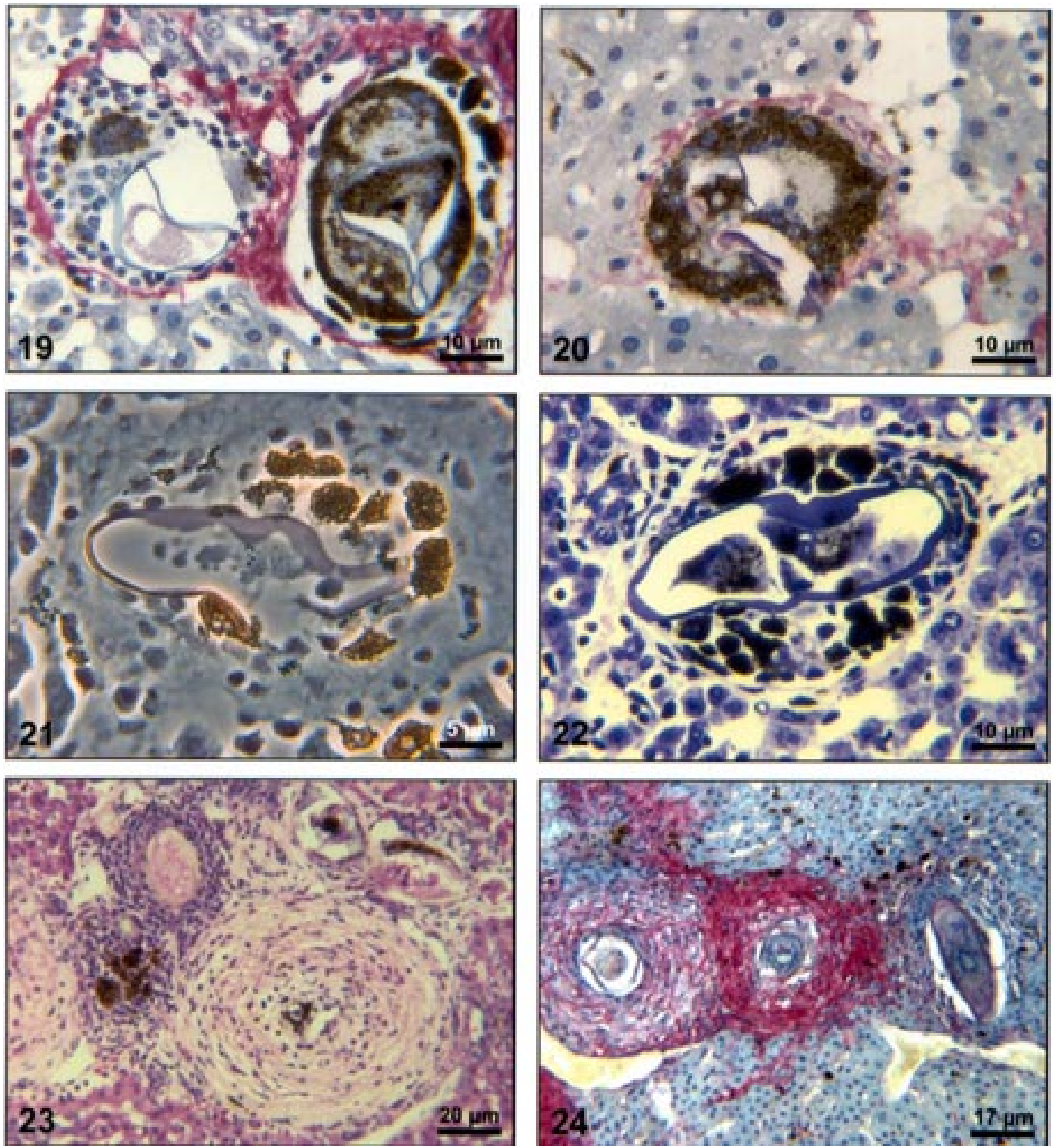

Hepatic schistosomal granulomas in naturally infected Nectomys squamipes - Involutional granulomas with thin collagenic layer (Figs 19, 20) or consisting predominantly of pigmented macrophages (Figs 21, 22), presenting sometimes small lymphocytes mingled with macrophages and giant cells (Fig. 19). Concomitant occurrence of granulomas in different stages of evolution or maturation, varying from involutional to advanced productive (Fig. 23) or from small macrophagic type to advanced fibrotic (Fig. 24) [Picrosirius (Figs 19, 20, 24); Lennert's Giemsa (Fig. 22) plus phase contrast (Fig. 21); H \& E (Fig. 23)]. 
lar reactions. The general morphological aspects of the granulomas in naturally infected animals when compared with the experimentally infected ones indicated, based on the characteristics of the more advanced granulomatous stages, that the infection was more chronic and certainly surpassed 52 days of infection. However, the data did not provide any conclusion whether the captured animals were infected only once or many times under natural conditions. Experimental studies have shown that $N$. squamipes is susceptible to reinfection (Maldonado Jr. et al. 1994). Surprisingly, there were not meaningful differences between the granuloma aspects of naturally infected N. squamipes and chronically infected C. callosus, which were infected only one time with $70 \mathrm{~S}$. mansoni cercariae (Lenzi 1998). In this work, N. squamipes with 52 days of infection exhibited more homogeneous granulomas due
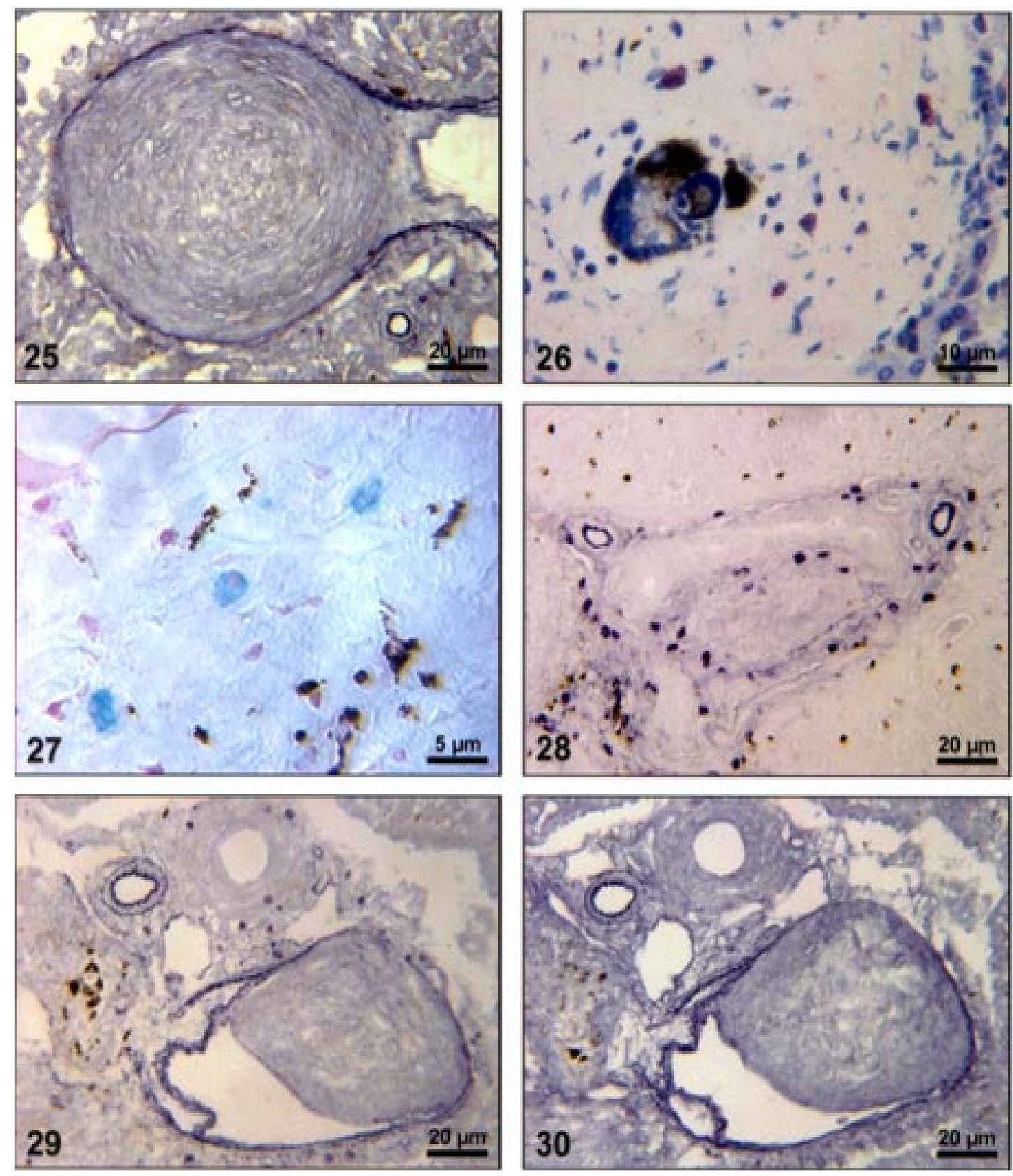

Hepatic schistosomal granulomas in naturally infected Nectomys squamipes - Intravascular granulomas sharply delineated by the vascular wall elastic fibers (Figs 25, 29, 30). Presence of mast cells inside granulomas (Figs 26, 27) and in connective tissue of portal space adjacent to granulomas (Figs 28-30). Mast cells were of mucosal type, rich in proteoglycans (Fig. 27), and were also resorcin-fuchsin positive (Fig. 29), becoming negative after oxidation (Fig. 30). [Weigert's resorcin-fuchsin without (Figs 28, 29) and with oxone (Figs 25, 30); Lennert's Giemsa (Fig. 26); Alcian blue-safranin plus pseudo-Nomarski (Fig. 27)]. 
to the short time of infection, although the granulomas were different from the mice, being predominantly of exudative-macrophage type. The survival of one animal naturally infected for more than 400 days in laboratory conditions (it was killed at 490 days after capture) (RodriguesSilva 1988) emphasized the resistance of $N$. squamipes to the infection and its putative weightiness to keep on maintaining the $S$. mansoni cycle in endemic areas where they play role as an alternative vertebrate host (D'Andrea et al. 2000).

N. squamipes like C. callosus (Lenzi et al. 1995), presented peculiar granulomas consisting predominantly of large macrophages, many of them full of schistosome pigment, characterizing a exudative-macrophage granuloma type, usually smaller than the equivalent granuloma type in mouse. They were composed by large macrophages
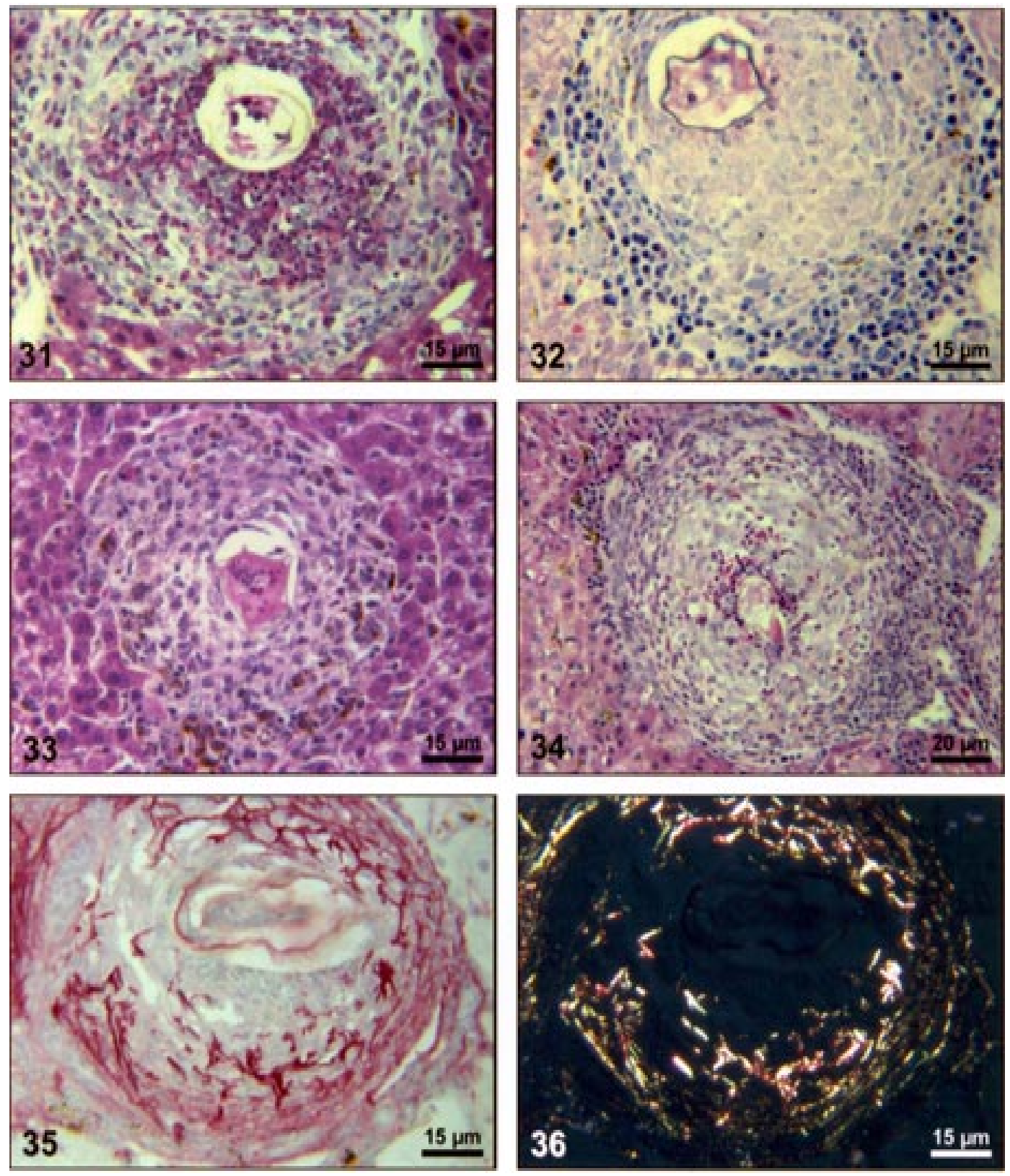

Hepatic schistosomal granulomas in experimentally infected Nectomys squamipes - Portal exudative-productive granulomas rich in eosinophils (Fig. 31) or composed by a macrophage core surrounded by lymphocytes and plasma cells (Figs 32, 34). Typical intraparenchymal macrophage granuloma essentially consisting of macrophages (Fig. 33). Exudative-productive granuloma with paracentral fibrogenesis forming a collagenous mesh interposed between the central and peripheral-concentric zones. [H \& E (Figs 32, 33, 34); Lennert's Giemsa (Fig. 32) Picrosirius without (Fig. 35) and with polarization microscopy (Fig. 36)]. 
with variable number of eosinophils, surrounded or not by mononuclear cells or were small and constituted by a macrophagic central layer surrounded by a thin collagenous and reticular pseudocapsule (Figs 3, 33, 37, 38). The frequent presence of intravascular granulomas as was seen in C. callosus (Lenzi et al. 1995) may be due to a periovular reaction inside the vessels with less granulocytes than in mice, poor in proteolytic enzymes responsible for corrosion of the vascular walls.
The presence of small parenchymatous necrotic foci in the presence of very well configured granulomas in both experimentally infected groups $(N$. squamipes and $\mathrm{C} 3 \mathrm{H} / \mathrm{He}$ mice) suggested that this event that happens more in acute phase of infection is not dependent on the granuloma efficiency to circumvent egg antigens and its pathogenesis is still unknown.

Large macrophages full of Schistosoma pigment in the granulomas, mainly of the involutional types, charac-
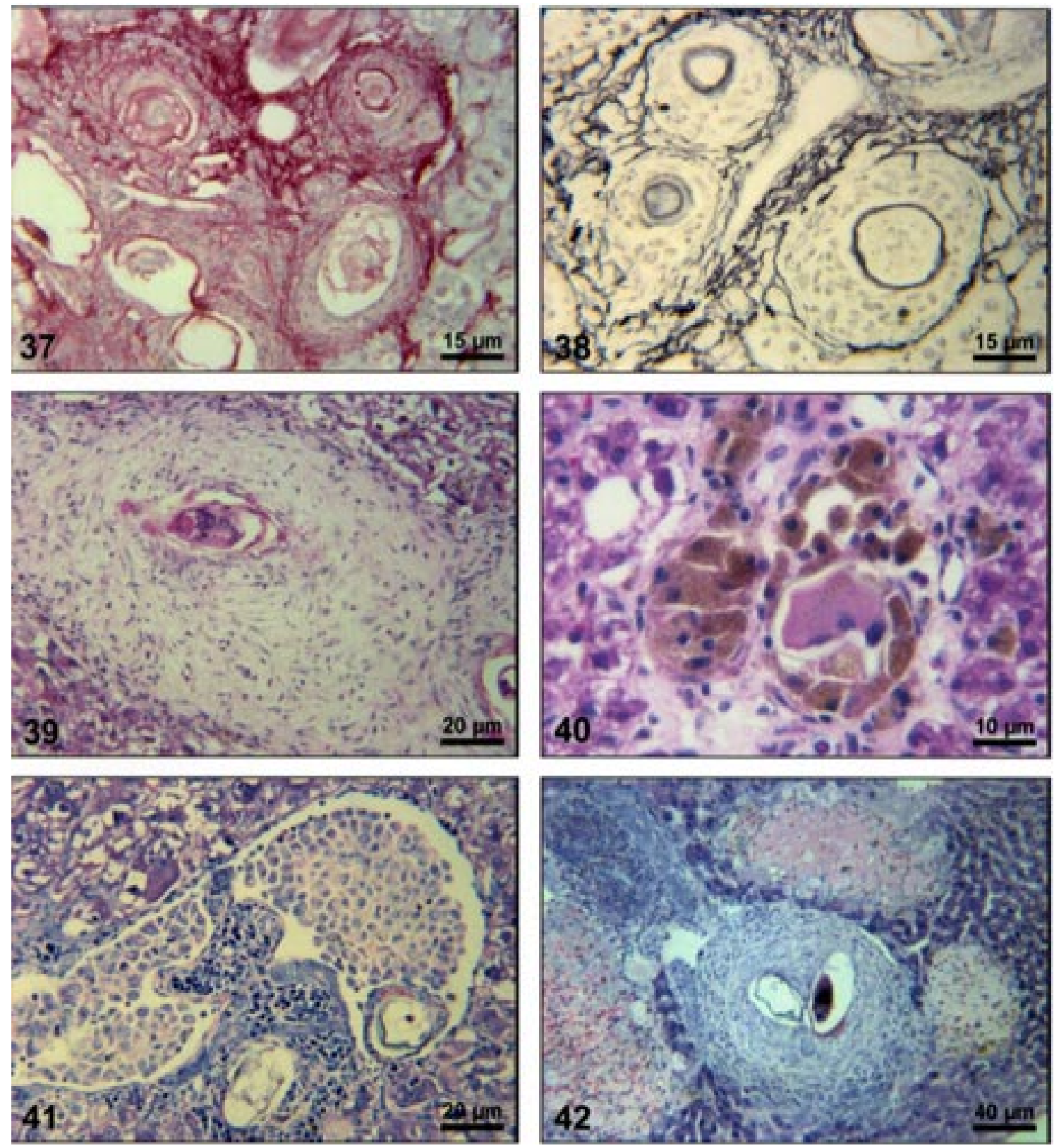

Hepatic schistosomal granulomas in experimentally infected Nectomys squamipes - Small macrophagic granulomas constituted by two clear zones: central or macrophagic and peripheral or fibrotic (Figs 37, 38). Advanced or fibrotic productive granuloma composed by fibroblast-like cells (Fig. 39). Involutional pigmented-macrophagic granulomas showing minimum evidence of residual fibrosis (Fig. 40). Dilated portal lymphatic vessels full of large and active macrophages (Fig. 41). Three necrotic areas located next to an exudativeproductive granuloma (Fig. 42). [Picrosirius (Fig. 37); Gomori for reticulum (Fig. 38); H \& E (Figs 39, 40); Lennert's Giemsa (Figs 41, 42)] 
terized another feature of $N$. squamipes infection that was similar to C. callosus (Lenzi et al. 1995, Lenzi 1998). Recently, this pigment was unequivocally identified as haemozoin (Hz), and similar to Plasmodium and Rhodnius prolixus, $\mathrm{S}$. mansoni produces $\mathrm{Hz}$ in order to detoxify the haem derived from haemoglobin digestion (Oliveira et al. 2000a). Therefore, Hz formation in the blood-feeding organisms seems to be an important mechanism to prevent generation of free radicals by haem released upon haemo- globin digestion (Slater et al. 1991, Oliveira et al. 1999, 2000a,b, Chen et al. 2001). Oliveira et al. (2002) demonstrated that the pro-oxidant activity of $\mathrm{Hz}$ depended on the crystal's size. Capron et al. (1965) proposed a causal relationship between pigment deposits and fibrogenesis in liver. However, Andrade and Andrade (1965), Stenger et al. (1967), Grimaud et al. (1976) and Lenzi et al. (1995, 1998 b) have indicated absence or low fibrogeneis around the pigmented-loaded cells. In fact, $\mathrm{Hz}$ effects on the
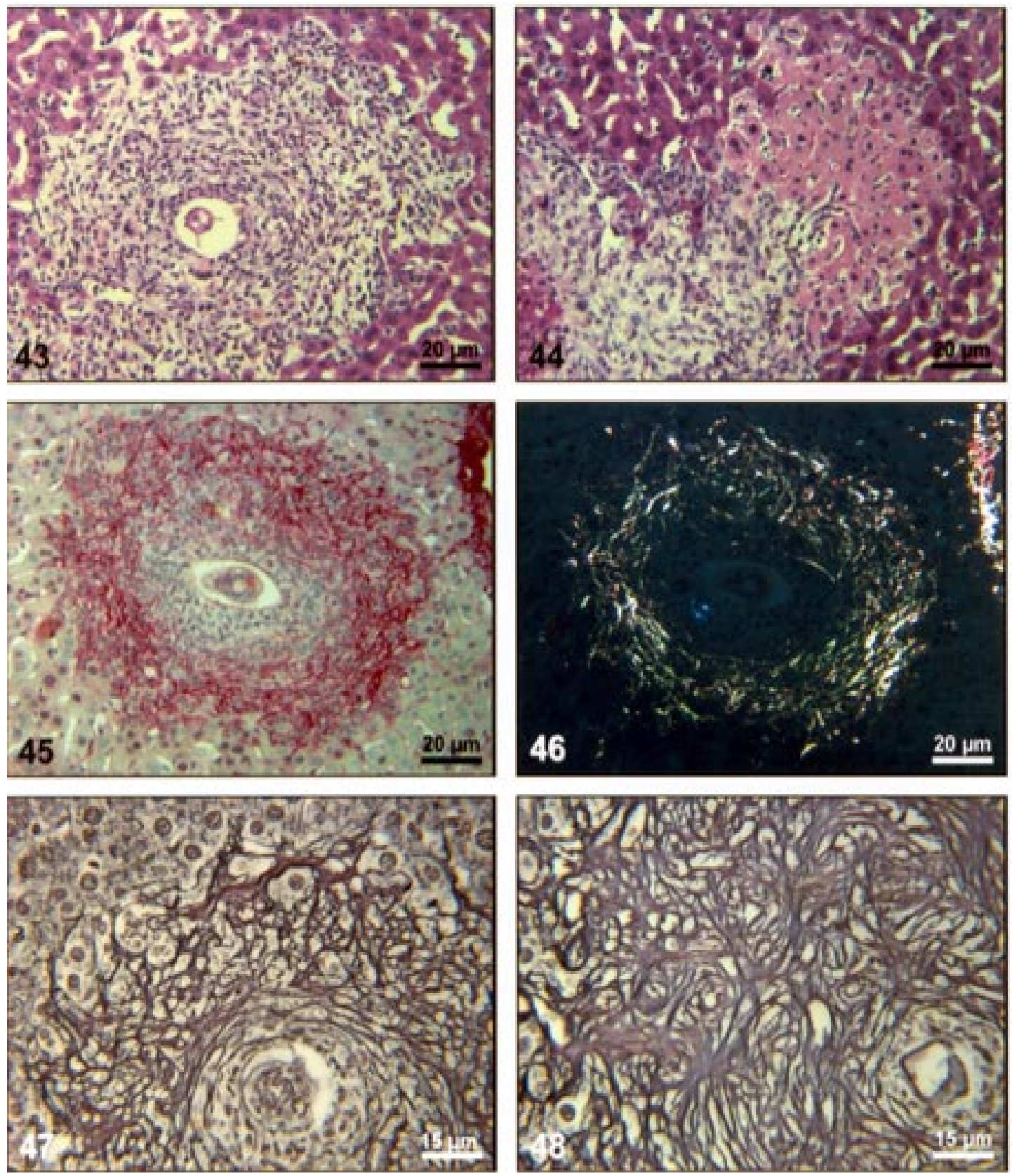

Hepatic schistosomal granulomas in experimentally infected $\mathrm{C}_{3} \mathrm{H} / \mathrm{He}$ mice - Exudative-productive granuloma with irregular external contour (Fig. 43). Parenchymatous necrotic area close to the periphery of one granuloma (Fig. 44). Exudative-productive granulomas composed by central-macrophagic and peripheral-fibrotic zones (Figs 45, 46), clearly showing several fiber anchorage points or fiber radiation centers (Figs 47, 48). [H \& E (Figs 43, 44); Picrosirius without (Fig. 45) and with polarization microscopy (Fig. 46); Gomori for reticulum (Figs 47, 48)]. 


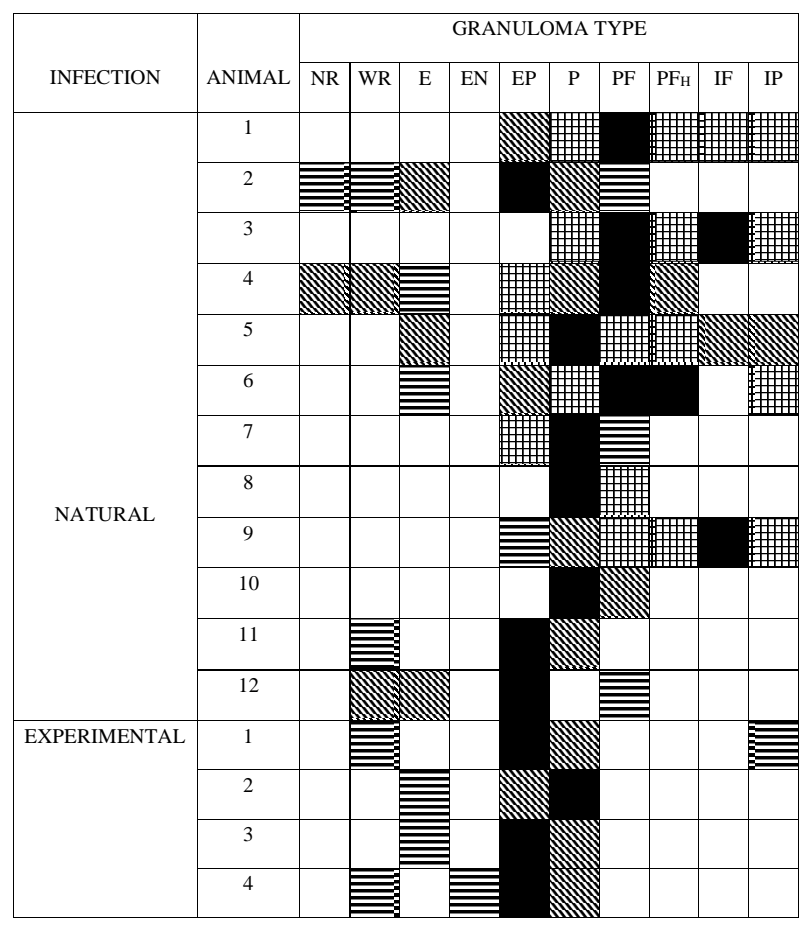

Fig. 49: natural and experimental Schistosoma mansoni infection in Nectomys squamipes. Distribution of hepatic granulomas according to Hsü et al. (1972) modified by Lenzi et al. (1998a). NR: no reaction; WR: weakly or initial reactive; E: exudative; EN: exudative-necrotic; EP: exudative-productive; P: productive; PF: productive-fibrotic; $\mathrm{PF}_{\mathrm{H}}$ : productive fibrotic with hyalinization; IF: involutional-fibrotic; IP: involutional-pigmented; $\square$ absent ; present; $\equiv$ rare; 曲 increase d; $\square$ predominant.

granuloma development and regulation were not well explored in the $\mathrm{S}$. mansoni pathogenesis, since $\mathrm{Hz}$ has been involved in many biological activities such as impairment of phagocytic function (Schwarzer \& Arese 1996), induction of lipoperoxidation (Schwarzer et al. 1996, Arese \& Schwarzer 1997), 4-hydroxynonenal (HNE) and hydroxyeicosatetraenoic acids (HETEs) production (Green et al. 1996), immunomodulations of macrophages affecting antigen processing, chemokine and cytokine secretion (Pichyangkul et al.1994, Green et al. 1996, Schwarzer et al. 1998, Scorza et al. 1999).

The frequent presence of multinucleated giant cells engulfing egg detritus in involutional $N$. squamipes granulomas was considered as indicative of their effect as schistosome egg scavenger after miracidia death instead of destructive cells. Multinucleated giant cell formation was also observed in olive baboon (Papio cynocephalus anubis) hepatic granulomas and, differently from our point of view, was presented as a cellular arrangement particularly efficient in bringing about the destruction of schistosome eggs and subsequent resolution of the egg granuloma without fibrosis (Farah et al. 2000).

$N$. squamipes involutional granulomas presented peculiar distribution of lymphocytes that were mixed with or around pigmented macrophages (Figs 17-20) and/or formed a ring around the granulomas (Fig. 18). So far there is no lymphocyte marker to Cricetidae family of animals

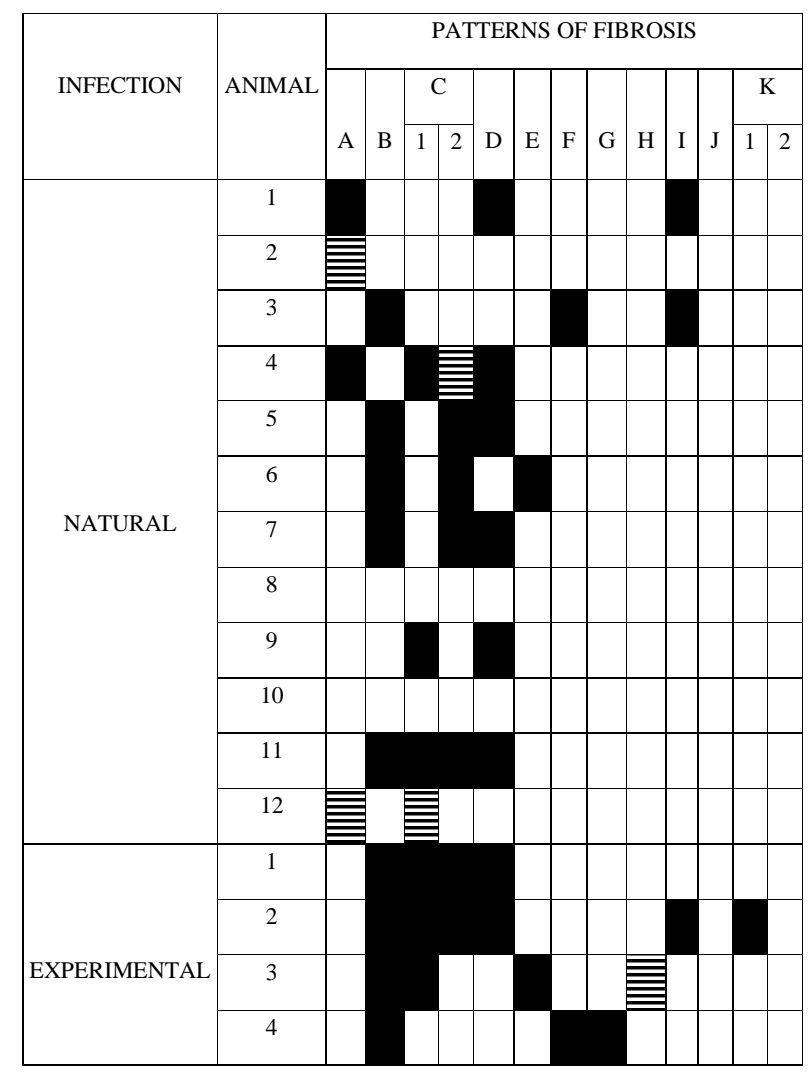

Fig. 50: natural and experimental Schistosoma mansoni infection in Nectomys squamipes. Patterns of hepatic fibrosis expressed by reticulin stain. A: portal; B: periportal; C: septal portal-portal; D: septal portal-central; E: septal central-central; F: focal (collapse) intralobular; G: focal and close to central region; H: focal-pericentral; I: capillary transformation of sinusoids; J: peripheral (angular); K:

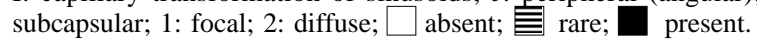

making it impossible to define the lymphocyte sub-populations. However, the lymphocytes in involutional granulomas can act as macrophage activators inducing the expression of tumor necrosis factor-alfa and matrix metalloproteinases (Fayyazi et al. 2000), accelerating the granuloma degradation and absorption.

Unlike C. callosus (Lenzi et al. 1995), another member of Cricetinae (Sigmodontinae) subfamily, N. squamipes presented a large number of mucosal mast cells in portal spaces and inside granulomas mainly of the proliferative fibrotic type (Figs 26-29). Fibroblasts are believed to promote mast cell survival and differentiation through the production of membrane-bound and soluble stem cell factor (SCF), which interact with c-kit on the surface of mast cells (Levi-Schaffer et al. 1986, Vliagoftis et al. 1999); they can also interact with mast cells through connexins, since mast cells express CX 43 an CX 32 (Oliani et al. 1995). Otherwise, mast cell-derived mediators and mast cell-related neutral proteases, tryptase and carboxypeptidase are potent fibrogenic factors that are capable of inducing fibroblast proliferation and type I collagen synthesis (Gailit et al. 2001). Mast cell mediators can also play a role in the regulation of myofibroblasts differentiation and function 
TABLE I

Morphometric analysis (mean and standard deviation) of hepatic schistosomal granulomas stained with haematoxiline-eosin from Nectomys squamipes (naturally and experimentally infected) and C3H/He mice. Significant differences $(\mathrm{p} \leq 0.05)$

\begin{tabular}{lcccc}
\hline $\begin{array}{l}\text { Morphometric } \\
\text { characters }\end{array}$ & $\begin{array}{c}\text { Nectomys squamipes } \\
\text { Natural infection }\end{array}$ & $\begin{array}{c}\text { Nectomys squamipes } \\
\text { Experimental infection }\end{array}$ & $\begin{array}{c}\text { Mus musculus } \\
\mathrm{C} 3 \mathrm{H} / \mathrm{He}\end{array}$ & $\mathrm{n}=73$ \\
& $\mathrm{n}=447$ & $\mathrm{n}=138$ & $81359 \pm 33985$ & $\mathrm{p}$ values \\
Area $\left(\mu \mathrm{m}^{2}\right)$ & $33590 \pm 18867$ & $47497 \pm 23451$ & $1121 \pm 281$ & 0.001 \\
Perimeter $(\mu \mathrm{m})$ & $708 \pm 214$ & $822 \pm 213$ & $261 \pm 62$ & 0.001 \\
Minor diameter $(\mu \mathrm{m})$ & $165 \pm 51$ & $204 \pm 55$ & $378 \pm 95$ & 0.001 \\
Major diameter $(\mu \mathrm{m})$ & $245 \pm 70$ & $282 \pm 71$ & 001 \\
\hline
\end{tabular}

TABLE II

Morphometric analysis (mean and standard deviation) of hepatic schistosomal granulomas stained with Gomori's reticulin in Nectomys squamipes (naturally and experimentally infected) and $\mathrm{C} 3 \mathrm{H} / \mathrm{He}$ mice. Significant differences $(\mathrm{p} \leq 0.05)$

\begin{tabular}{lcccr}
\hline $\begin{array}{l}\text { Morphometric } \\
\text { characters }\end{array}$ & $\begin{array}{c}\text { Nectomys squamipes } \\
\text { Natural infection }\end{array}$ & $\begin{array}{c}\text { Nectomys squamipes } \\
\text { Experimental infection }\end{array}$ & $\begin{array}{c}\text { Mus musculus } \\
\text { C3H/He }\end{array}$ & $\mathrm{n}=76$ \\
\hline $\mathrm{n}=116$ & $\mathrm{n}=57$ & $73735 \pm 28291$ & 0.001 \\
Area $\left(\mu \mathrm{m}^{2}\right)$ & $31390 \pm 15718$ & $39081 \pm 16096$ & $332 \pm 65$ & 0.001 \\
Perimeter $(\mu \mathrm{m})$ & $220 \pm 55$ & $245 \pm 48$ & $282 \pm 54$ & 0.001 \\
Minor diameter $(\mu \mathrm{m})$ & $179 \pm 47$ & $198 \pm 43$ & $331 \pm 65$ & 0.001 \\
Major diameter $(\mu \mathrm{m})$ & $221 \pm 54$ & $245 \pm 49$ & \\
\hline
\end{tabular}

(Horobin \& Flemming 1980). Mast cells exhibited staining characteristics similar to elastic fibers, showing attenuation and even null reaction after oxidation by oxone probably due to conversion of disulfide bridges to anionic sulphonic acid derivatives, changing the affinities to the basic dye compounds of the Weigert's method (Figs 29, 30) (Bogomoletz 1980, Avraham et al. 1989).

The extragranulomatous and/or portal fibrosis in $N$. squamipes liver, like in mice, never acquired Symmer fibrosis pattern, but sometimes produced local obstruction of portal lymphatic vessels causing focal lymphangiectasis full of macrophages (Fig. 41). The lymphatic vessels in portal tracts drain the Disse spaces and although the lymph flows in the same direction as the bile, opposite to that of the blood (Thung \& Gerber 1992), there was no evidence of biliary obstruction.

In conclusion, the results showed that $N$. squamipes, natural and experimentally infected with $S$. mansoni, reproduced, with small variations, the hepatic granuloma aspects already described in cricetidium (C. callosus) (Lenzi et al. 1995, Lenzi 1998b), showing a genetic tendency to set up strong macrophage responses and small granulomas. Unexpectedly, natural infection did not engender distinguished histopathological characteristics distinct from those derived from experimental single infection, showing changes predominantly secondary to the duration of infection. It appears that the variability of the inocula (and the number of infections?) interfere more with the quantity than with the quality of the pathological changes, denoting some morpho-functional determinism in the response to schistosomal infection dependent on the animal species.

\section{ACKNOWLEDGEMENTS}

To Ms Luzia de Fátima Gonçalves Caputo from Pathology Department, Oswaldo Cruz Institute, for her expert technical assistance. To Genilton José Oliveira and Heloísa Maria Nogueira Diniz from Education Department, Oswaldo Cruz Institute, for preparation of figures.

\section{REFERENCES}

Alarcón de Noya B, Pointier JP, Colmenares C, Théron A, Balzan C, Cesari IM, González S, Noya O 1997. Natural Schistosoma mansoni infection in wild rats from Guadeloupe: parasitological and immunological aspects. Acta Tropica 68: 11-21.

Andrade ZA, Andrade SG 1965. Patologia do baço na esquistossomose hepatoesplênica. Rev Inst Med Trop São Paulo 7: 218-227.

Arese P, Schwarzer E 1997. Malarial pigment (haemozoin): a very active 'inert' substance. Ann Trop Med Parasitol 91: 501-516.

Avraham S, Austen KF, Nicodemus CF, Gartner MC, Stevens RL 1989. Cloning and characterization of the mouse gene that encodes the peptide core of secretory granule proteoglycans and expression of this gene in transfected rat-1 fibroblasts. J Biol Chem 264: 16719-16726.

Bogomoletz W 1980. Avantages de la coloration par le rouge Sirius de l'amyloïde et des éosinophiles. Arch Anat Cytol Pathol 28: 252-253.

Bonvicino CR, D’Andrea PS, Cerqueira R, Seuánez HN 1996. The chromossomes of Nectomys (Rodentia, Cricetidae) with $2 \mathrm{n}=52,2 \mathrm{n}=56$, and interspecific hybrids $(2 \mathrm{n}=54)$. Cytogenet Cell Genet 73: 190-193.

Capron A, Deblock S, Biguet J, Clay A, Adenis L, Vernes A 1965. Contribuition à l'étude experimentale de la bilharziose à Schistosoma haematobium. Bull Org Mond Santé 32: 755778. 
Carson FL, Martin JH, Lynn JA 1973. Formalin fixation for electron microscopy. A re-evaluation. Am J Clin Pathol 59: 365-373.

Cheever AW, Jankovic D, Yap GS, Kullbeg MC, Sher A, Wynn $\mathrm{T}$ 1998. Role of cytokines in the formation and downregulation of hepatic circumoval granulomas and hepatic fibrosis in Schistosoma mansoni-infected mice. Mem Inst Oswaldo Cruz 93 (Suppl. I): 25-32.

Chen MM, Shi L, Sullivan Jr. DJ 2001. Haemoproteus and Schistosoma synthesize heme polymers similar to Plasmodium hemozoin and $\beta$-hematin. Mol Biochem Parasitol 113: $1-8$.

D'Andrea PS, Maroja LS, Gentile R, Cerqueira R, Maldonado Jr. A, Rey L 2000. The parasitism of Schistosoma mansoni (Digenea:Trematoda) in a naturally infected population of water rats, Nectomys squamipes (Rodentia:Sigmondontinae) in Brazil. Parasitology 120: 573-582.

Duplantier JM, Senè M 2000. Rodents as reservoir hosts in the transmission of Schistosoma mansoni in Richard-Toll, Senegal, West Africa. J Helminthol 74: 129-135.

Farah IO, Nyindo M, King CL, Hau J 2000. Hepatic granulomatous response to Schistosoma mansoni eggs in BALB/c mice and olive baboons (Papio cynocephalus anubis). J Comp Pathol 123: 7-14.

Fayyazi A, Schweyer S, Eichmeyer B, Herms J, Hemmerlein B, Radzun HJ, Berger H 2000. Expression of IFN gamma, coexpression of TNF alpha and matrix metalloproteinases and apoptosis of T lymphocytes and macrophages in granuloma annulare. Arch Dermatol Res 292: 384-390.

Gailit J, Marchese MJ, Kew RR, Gruber BL 2001. The differentiation and function of myofibroblasts is regulated by mast cell mediators. J Invest Dermatol 117: 1113-1119.

Green MD, Xiao L, Lal AA 1996. Formation of hydroxyeicosatetraenoic acids from hemozoin-catalyzed oxidation of arachidonic acid. Mol Biochem Parasitol 83: 183186.

Grimaud JA, Borojevic R, Santos HA 1976. Schistosomal pigment in human and murine infections with Schistosoma mansoni. Trans $R$ Soc Trop Med Hyg 70: 73-77.

Horobin RW, Flemming L 1980. Structure-staining relationships in histochemistry and biological staining. II. Mechanistic and practical aspects of the staining of elastic fibres. $J$ Microsc 119: 357-372.

Hsü SYL, Hsü HF, Davis JR, Lust GL 1972. Comparative studies on the lesions caused by eggs of Schistosoma japonicum and Schistosoma mansoni in livers of albino mice and rhesus monkeys. Ann Trop Med Parasitol 66: 8997.

Junqueira LCU, Bignolas G, Brentani RR 1979. Picrosirius staining plus polarization microscopy, a specific method for collagen detection in tissue sections. Histochem J 11: 447455.

Lennert K 1978. Malignant Lymphomas other than Hodgkin's Disease, Springer-Verlag, Berlin, 833 pp.

Lenzi HL, Kimmel E, Schechtman H, Pelajo-Machado M, Romanha WS, Pacheco RG, Mariano M, Lenzi JA 1998a. Histoarchiteture of schistosomal granuloma development and involution: morphogenetic and biomechanical approaches. Mem Inst Oswaldo Cruz 93 (Suppl. I): 141-151.

Lenzi JA 1998. Estudo do Modelo Calomys callosus Rengger, 1830 (Rodentia: Cricetidae) na Infecção por Schistosoma mansoni Sambon, 1907. Parâmetros Parasitológicos e Histopatológicos, PhD Thesis, Universidade Federal da Bahia, Bahia.

Lenzi JA, Mota EM, Pelajo-Machado M, Paiva RAN, Lenzi HL 1995. Calomys callosus: an alternative model to study fibrosis in schistosomiasis mansoni. The pathology of acute phase. Mem Inst Oswaldo Cruz 90: 311-318.

Lenzi JA, Pelajo-Machado M, Mota EM, Oliveira DN, Panasco MS, Andrade ZA, Lenzi HL 1998b. Effects of schistosomal mansoni infection on Calomys callosus coelom-associated lymphomyeloid tissue (milky spots). Mem Inst Oswaldo Cruz 93 (Suppl. I): 13-23.

Levi-Schaffer F, Austen KF, Gravallese PM, Stevens RL 1986. Coculture of interleukin 3-dependent mouse mast cells with fibroblasts results in a phenotypic change of the mast cells. Proc Natl Acad Sci USA 83: 6485-6488.

Luque EH, Montes GS 1989. Progesterone promotes a massive infiltration of the rat uterine cervix by the eosinophilic polymorphonuclear leukocytes. Anat Rec 223: 257-265.

Machado-Silva JR, Galvão C, Presgrave OAF, Rey L, Gomes DC 1994. Host-induced morphological changes of Schistosoma mansoni Sambon, 1907 male worms. Mem Inst Oswaldo Cruz 89: 411-414.

Machado-Silva JR, Lanfredi RM, Gomes DC 1997. Morphological study of adult male worms of Schistosoma mansoni by scanning electron microscopy. Mem Inst Oswaldo Cruz. 92: 647-653.

Maldonado Jr. A, Machado-Silva JR, Rodrigues-Silva R, Lenzi HL, Rey L 1994. Evaluation of the resistance to Schistosoma mansoni infection in Nectomys squamipes (Rodentia:Cricetidae), a natural host of infection in Brazil. Rev Inst Med Trop São Paulo 36: 193-198.

Morand S, Pointier JP, Théron A 1999. Population biology of Schistosoma mansoni in the black rat: host regulation and basic transmission rate. Int J Parasitol 29: 673-684.

Oliani SM, Girol AP, Smith RL 1995. Gap junctions between mast cells and fibroblasts in the developing avian eye. Acta Anat (Basel) 154: 267-271.

Oliveira MF, d'Ávila JCP, Torres CR, Oliveira PL, Tempone AJ, Rumjanek FD, Braga CMS, Silva JR, Dansa-Petretski M, Oliveira MA, de Souza W, Ferreira ST 2000a. Haemozoin in Schistosoma mansoni. Mol Biochem Parasitol 111: 217-221.

Oliveira MF, Silva JR, Dansa-Petretski M, de Souza W, Lins U, Braga CMS, Masuda H, Oliveira PL 1999. Haem detoxication by an insect. Nature 400: 517-518.

Oliveira MF, Silva JR, Dansa-Petretski M, de Souza W, Lins U, Braga CMS, Masuda H, Oliveira PL 2000b. Haemozoin formation in the midgut of the blood-sucking insect Rhodnius prolixus. FEBS Letters 477: 95-98.

Oliveira MF, Timm BL, Machado EA, Miranda K, Attias M, Silva JR, Dansa-Petretski M, Oliveira MA, de Souza W, Pinhal NM, Sousa JJF, Vugman NV, Oliveira PL 2002. On the pro-oxidant effects of haemozoin. FEBS Letters 512: 139-144.

Pichyangkul S, Saengkrai P, Webster HK 1994. Plasmodium falciparum pigment induces monocytes to release high levels of tumor necrosis factor- $\alpha$ and interleukin-1 $\beta$. Am $J$ Trop Med Hyg 51: 430-435.

Rey L 1993. Non-human vertebrate hosts of Schistosoma mansoni and schistosomiasis transmission in Brazil. Res Rev Parasitol 53: 13-25.

Ribeiro AC, Maldonado Jr. A, D'Andrea PS, Vieira GO, Rey L 1998. Susceptibility of Nectomys rattus (Pelzen, 1883) to experimental infection with Schistosoma mansoni (Sambon, 1907): a potential reservoir in Brazil. Mem Inst Oswaldo Cruz 93: 295-299.

Rodrigues-Silva R 1988. Nectomys squamipes e Akodon arviculoides (Rodentia: Cricetidae) como Hospedeiros Naturais do Schistosoma mansoni em Sumidouro (RJBrasil). Emprego do Nectomys como Modelo Alternativo no Estudo da Esquistossomose Mansoni, MSc Thesis, Instituto Oswaldo Cruz, Rio de Janeiro, 147 pp. 
Rodrigues-Silva R, Machado-Silva JR, Faerstein NF, Lenzi HL, Rey L 1992. Natural infection of wild rodents by Schistosoma mansoni. Parasitological aspects. Mem Inst Oswaldo Cruz 87: 271-276.

Schwarzer E, Alessio M, Ulliers D, Arese P 1998. Phagocytosis of the malarial pigment, impairs expression of major histocompatibility complex class II antigen, CD54, and CD11c in human monocytes. Infect Immun 66: 1601-1608.

Schwarzer E, Arese P 1996. Phagocytosis of malarial pigment hemozoin inhibits NADPH-oxidase activity in human monocyte-derived macrophages. Biochem Biophy Acta 1316: 169175.

Schwarzer E, Muller O, Arese P, Siems WG, Grune T 1996. Increased levels of 4-hydroxynomenal in human monocytes fed with malarial pigment hemozoin. FEBS Letters 388: 119-122.

Scorza T, Magez S, Brys L, Baetselier P 1999. Hemozoin is a key factor in the induction of malaria-associated imunosupression. Parasite Immnunol 21: 545-554.

Slater AFG, Swiggard WJ, Orton BR, Flitter WD, Goldberg DE, Cerami A, Henderson GB 1991. An iron-carboxylate bond links the heme units of malaria pigment. Proc Natl Acad Sci USA 88: 325-329.

Souza VAM, Rodrigues-Silva R, Maldonado Jr. A, MachadoSilva JR, Rey L 1992. Nectomys squamipes (Rodentia: Crice- tidae) as an experimental model for schistosomiasis. Mem Inst Oswaldo Cruz 87: 277-280.

Stenger RJ, Warren KS, Johnson EA 1967. An electron microscopic study of the liver parenchyma and schistosome pigment in murine hepatoesplenic schistosomiasis mansoni. Am J Trop Med Hyg 16: 473-482.

Strobel S, Miller HPR, Ferguson A 1981. Human intestinal mucosal mast cells: evaluation of fixation and techniques. J Clin Pathol 34: 851-858.

Théron A, Pointier JP, Morand S, Imbert-Establet D, Borel G 1992. Long-term dynamics of natural populations of Schistosoma mansoni among Rattus rattus in patchy environment. Parasitology 104: 291-298.

Thung SN, Gerber MA 1992. Liver. In SS Stephen, Histology for Pathologists, Raven Press, New York, p. 625-638.

Vale BS, Pelajo-Machado M, Panasco MS, Lenzi JA, Lenzi HL 1997. Fluorescent stainings for mast cell and eosinophil study by confocal laser scanning microscopy. Cell Vision 4 : 198-199.

Vieira S 1991. Introdução à Bioestatística, Campus, Rio de Janeiro, 203 pp.

Vliagoftis H, Hutson AM, Mahmudi-Azer S, Kim H, Rumsaeng V, Oh CK, Moqbel R, Metcalfe DD 1999. Mast cells express connexins on their cytoplasmic membrane. J Allergy Clin Immunol 103: 656-662. 